Article

\title{
Implementation and Unification of the ERP System in a Global Company as a Strategic Decision for Sustainable Entrepreneurship
}

\author{
Michal Pohludka ${ }^{1}$, Hana Stverkova ${ }^{2, *}$ (1) and Beata Ślusarczyk ${ }^{3,4}$ (1) \\ ZKV Career, s.r.o., Chomutovska 38/10, 16100 Prague, Czech Republic; michal@zkvcareer.com \\ 2 Department of Business Administration, Faculty of Economics, VSB-Technical University of Ostrava, \\ 17. listopadu 15/2172, 70833 Ostrava, Czech Republic \\ 3 The Management Faculty, Czestochowa University of Technology, Armii Krajowej 19B, 42-201 Częstochowa, \\ Poland; jagoda@zim.pcz.pl \\ 4 Faculty of Economic Sciences and IT, North-West University, Vaal Triangle Campus, P.O. Box 1174, \\ Vanderbijlpark 1900, South Africa \\ * Correspondence: hana.stverkova@vsb.cz; Tel.: +42-059-732-2217
}

Received: 9 July 2018; Accepted: 9 August 2018; Published: 16 August 2018

\begin{abstract}
This article considered factors connected with the implementation and unification of an ERP (Enterprise Resource Planning) system, and their influence on the sustainable development of global companies. It showed a cognitive model on such impact and gave an example in the form of a case study of a global company listed on the NASDAQ Stock Exchange. The basic strategic objectives of each organization include long-term growth and sustainability. In a growing competitive environment, it is essential to manage the company effectively. This can be achieved provided that the company's organizational structure and operations are properly set from the point of view of the ERP system. The research results were aimed at creating the generalized process of the ERP system's gradual implementation, to make the development of an organization progressive. The paper was focused on describing the implementation and unification of the Enterprise Resource Planning System, in a global company listed on the NASDAQ Stock Exchange. The aim of the paper was to monitor and evaluate, the links between Enterprise Resource Planning and Customer Relationship Management. This process is time consuming and costly. To achieve the aim, the case study was carried out in the form of an expert survey aimed at assessing the impact of the unification and implementation of the ERP system in a global company. The study included methods of systemic analysis, methods of sociological expert survey, a method of qualitative peer review, and a method for a cognitive model. It leads not only to effective management of global companies but enables the monitoring and comparison of Key Performance Indicators and the Net Promoter Score in each country, using the same parameters. The implementation of a unified Enterprise Resource Planning system leads to a significant cost reduction and has a positive impact on the financial indicators reported on the stock exchange. This study highlighted the importance of the implementation of an effective ERP system, to make the development of organizations sustainable.
\end{abstract}

Keywords: customer relationship management system; enterprise resource planning system; global company; key performance indicators; new technologies; net promoter score; organizational structure; strategic development; sustainability

\section{Introduction}

In recent years, the Fourth Industrial Revolution, also called Industry 4.0, has been manifesting its effects on the economy and hence corporate governance. Long-term growth and maximization of 
market share is the primary objective for all businesses. Entrepreneurial intentions, entrepreneurs' state of mind that directs attention, experience, and action toward a business concept set the form and direction of the organization [1]. With growing globalization, it is increasingly difficult to achieve this goal, as a limited number of leading players appear on global markets in each segment. The research carried out by Žižka et al. [2] showed such a phenomenon, where the concentration of industry was associated with research and development activities. Organizations invested their resources to further product development, professional marketing communications, and acquisition activities $[3,4]$. Research by Orlova et al. [5] confirmed that the specifics of the external business environment, are related to sustainable development. These are not only a significant element of growth for the big players, but they are gaining an ever more significant market share. In the last decade, the number of acquisitions increased considerably, leading to an even more limited number of players in the global markets. This fact prompts the need for much more efficient company management, as well as management, of all internal and external activities. Hence, it is difficult to foretell evolutions in competitiveness because of the great uncertainty $[6,7]$.

Effective company management is possible provided that the organizational structure is correctly set up, as described by Stverkova and Pohludka [8]. This key prerequisite is important from several points of view. The first one, is a clear definition of the competences and responsibilities of each employee. Another, is the ability to effectively manage, motivate and develop employees, as well as track their performance and fulfillment of Key Performance Indicators (KPIs) [9]. According to Boyd and Reuning-Elliot [10], a well-established organizational structure becomes the basis for both effective and fast communication between the top management of a company and its employees, as well as between individual departments, for example, between the sales, marketing, and finance departments [11].

Apart from the organizational structure, it is necessary for a company's management to have established and systematic day-to-day business operations. In small companies, this need disappears, as management and their employees have a direct communication line, and these companies have all their components interconnected and, in most cases, physically situated in one building or at least one country. As for companies operating in global markets, such a system setting is essential to its operation. Their goal is to operate on a single platform, in each of its branches globally. A limited number of providers can provide such a solution, resulting in a high purchase price, high maintenance costs, and a relatively high rigidity of the system, as it is created universally and for feasibility in every company.

Having a single system platform in each country, depends on the Enterprise Resource Planning system (ERP). Production planning and scheduling is one of the most important components of an ERP system. The setting of the planning parameters has a key effect on the following factors: lateness, capital commitment, and throughput [12]. This is the starting point for the entire company setting. The ERP system is used by all company components. Its implementation or eventual unification is an extremely demanding process [13]. Those companies that have a long-term vision from an operational point of view, in which they expect rapid growth and expansion into other countries, and that also already have a unified ERP platform, are at an advantage [14,15]. However, this advantage relates to a very limited number of companies. In particular, it relates to those companies that had established themselves in the period when global ERP solutions became available and when globalization had begun to be taken into consideration as an emerging trend, due to the arrival of new technologies [16]. All other large-scale companies that had been on the market for more than twenty years were still awaiting the process of ERP system unification. The implementation of a unified ERP system in all branches of the world, manufacturing plants, logistics centers, and other company centers is a complex and costly process, such that many companies postpone this strategic decision [17]. Consequently, the management of the entire company suffers from enormous complexity, and as companies grow, this problem deepens [18]. 
Companies listed on financial markets are obliged to report their results on a quarterly basis. In quarterly reports, they announce their actual results, their comparisons with the last year and their outlook for future periods. Based on these results, the market situation, and global sentiment, the value of their shares change, and thus, the whole company.

However, in some respects, companies track their results on a daily basis. These results are the basis for management of the business and marketing activities [19], production, warehousing, etc. [20]. Therefore, it is important to connect the ERP system to the Customer Relationship Management (CRM) [21] system, enabling the company to manage business opportunities and predict fairly accurately, business results, i.e., the numbers of pieces sold within a defined time horizon. Therefore, this provides valuable data for production planning, warehouse management, and management on its capability of managing a current or long-term strategy [22].

The aim of this article was to provide a methodical approach, and a realistic example of introducing a unified ERP system within a global company listed on the NASDAQ Stock Exchange. Another objective was to assess the interconnectedness of a company's ERP system with the CRM system, and to point out the advantages of a unified operational platform where, despite time, financial demands, and the loss of sales, it is reflected as an investment in the future of the company. With a unified platform, the company gains flexibility in operations and communications, and has the ability to grow and expand into other countries, and acquire other companies.

The study, in the form of an expert survey, focused on assessing the barriers affecting the implementation and unification of the ERP system, was provided to find out critical success factors influencing the ERP implementation in global companies.

\section{Literature Review and Background}

A key factor within a global company, is that their operations and daily activities function using the same software platform. Unfortunately, this is not the case in a large number of global companies, as well as medium-sized companies, since they were established at a time when the degree of globalization was lower and their operations fitted within their national settings. It was assumed that each branch operated independently of the others and of the whole and they had their own systems, operations, and management structure.

This article considers the factors influencing the sustainable development of global companies and shows the cognitive model on such impact, giving an analysis of a scenario modelled on a global company listed on the NASDAQ Stock Exchange.

\subsection{The Enterprise Resource Planning System as a Strategic Decision}

A prerequisite of growth for global companies is that they have to react swiftly to market events, be able to implement individual steps in every branch around the world and have the capacity to strategically manage the company as a whole [19]. The unification of all the company's processes, organizational structures, marketing and business strategies, and also the operational platforms is crucial to achieve this result. For this reason, the most influential element of a company is its ERP system $[17,23]$.

Once a company has a unified ERP system, its total administrative operation-financial, warehousing, logistics and commercial—becomes transparent in nature and provides a large number of advantages. This company transparency and possible acquisition activities with integration of the purchased companies, or the sale of a part of the company (e.g., production lines or companies in a specific geographical region), or the sale of the whole company, are important from a managerial perspective and from the investors perspective [24]. Therefore, a unified ERP system, despite the implementation costs, substantially increases a company's value because of transparency and reduced operational threats [25].

The decision to unify the ERP system depends on many parameters [12]. Furthermore, the timing of this decision is unique to each company. However, it can generally be said that implementation 
occurs when the company achieves significant turnover to carry it out, and the existing system from an operational perspective no longer appears satisfactory, as described by Venkatraman [24]. Another reason may be strategic acquisitions, either purchase or sale, and the subsequent harmonization of all processes into one programme. The parameters that influence the implementation decision of a unified ERP system include the company's turnover, number of employees, number of products, number of countries where the company is represented, and mainly the company's long-term strategy [22,26]. Maddison Warren [25] noted if the strategy is aggressive or ambitious, the unification and implementation of the ERP system is an unavoidable step. Venkatraman and Fahd, highlight that implementation of the ERP system is considered an important strategy to establish new robust accounting practices, to improve the company survival rate [24].

The economic systems, or economic software, are systems that support most basic processes, such as tax record keeping, accounting, purchasing, sales, invoicing, salaries, and other administrative tasks [26]. They are designed for small firms and entrepreneurs that cannot afford an extensive information system, such as an ERP. In this paper, the authors examine the implementation and unification of an ERP system in a global company, as a strategic decision, leading to a sustainable business.

\subsection{A Process of the Enterprise Resource Planning System Implementation}

The implementation of information system functions requires a basic understanding of information technology. Information technology may exist outside the scope of an information system. An information system can be divided into economic (accounting) and ERP (management) systems. These two types are distinguished by the degree of reach of each activity of a firm and what target group they are intended for [27].

The definition of enterprise-wide applications of the ERP type, are focused on various aspects of their benefits and the following examples are given in Reference [28].

- Enterprise Resource Planning systems presents a method of effective planning and management of all enterprise resources in a manufacturing or distribution business, or in a business from the service sector. These resources are essential for accepting and completing a customer's order, including delivery and invoicing [12,24].

- Enterprise Resource Planning systems introduce software tools to manage business data. ERP systems help businesses with the supply chain, receipt of materials, warehouse management, acceptance of orders from customers, production planning, shipment of goods, accounting, human resources management, and other business roles and activities [25,28].

- Enterprise Resource Planning systems present a business program system in one package. The system enables the automation and integration of most of the business processes, communication of shared data, and practical matters within the whole company [26].

These definitions establish that the ERP system presents a set of integrated applications that enable the creation of a unified environment for the automation of planning, accounting, inspection, and analysis of all key business processes. It also creates and interconnects the environment for logistics, distribution, and warehouse management. In short everything connected to the financial administration of the whole company. Therefore, their value and other parameters can be monitored and seen at any time [29].

With regards to technological principles, the main principle of the ERP system is the integration of all departments and roles of a company into a single computer system. The most difficult is the creation of a unified system satisfying the requirements of the employees, the financial and the HR departments, the warehouse, and other units. The reason is that each of these departments generally has its own information system that is optimized for their specific needs. The ERP system joins together all the IT Systems, into one integrated program that forms a database [25]. Therefore, all the departments can quickly and easily share information and maintain communication [27]. 
During the implementation process, the business must obtain not only an adequate and functioning ERP system, but ensure the technical preparedness of its own employees to use the system independently. Implementing the ERP system is accompanied by a correction process (optimization), of the organizational structure and the systemization of the jobs in the business, as well as the process of its activities. It is necessary in terms of the security of the effectiveness of the business's management process as a whole to consider their usefulness as a basic criterion for changes [19,30].

The process of ERP system implementation is unique in each specific case, and has a definite period and outcome [31]. It is necessary to commence the ERP implementation project by formulating goals. The project must be defined: What forms the specific content of the project; what material resources are needed; which departments (divisions) and business activities are affected, and which ERP subsystems are scheduled for implementation. An official agreement defining these specifics is usually drawn up between the firm and client [27] to carry out the implementation. The implementation project is traditionally divided into stages, and each stage commences upon the completion and approval of the results of the previous stage.

The implementation project should be divided into the following stages as described in References [22,31]:

- Research into the subject of implementation.

- Project documentation and the organization of its implementation.

- Preparation of a test run.

- Test run.

- Commencement.

The implementation of a unified ERP system is a strategic decision of the company that entails extreme costs, a short-term decline in sales, involvement of many company employees, and a negative impact on the services provided to customers at the time of implementation [29]. That is why the whole process requires the attention of a company's top management, and its progress is communicated to the shareholders [16,24].

The global unification of the ERP system and its implementation has four basic phases:

- Decision-making at the company management level, target setting, and setting time and financial framework [23,32].

- Preparatory phase where a team of people responsible for ERP implementation is set up and a detailed plan is created. An exact timetable is created. All steps are set to achieve the goal, and threats and possible obstacles defined $[18,33,34]$.

- Execution of ERP system implementation. This phase has a clear timeframe, including all necessary, downstream activities [15,30,35].

- Monitoring development after implementation. Elimination of negative effects, current responses to country developments and involvement of local teams in support activities, and external communication with customers, people, or institutions affected $[23,36]$.

Deciding about introducing a unified ERP system within a global company, is solely the remit of the board of directors of the company. Based on a long-term vision and plans, a decision is made, taking into account all possible aspects. The main ones include, the long-term direction of the company, acquisition plans, or the preparation of the company for sale. The board of directors chooses an executive implementation team that is fully competent from a technical and managerial point of view. This team manages the entire process, sets execution plans, creates different patterns of progress, and directs the entire project towards the target.

The preparatory phase is key to the entire ERP implementation process [26]. The better the preparation, the more successful the implementation process, and the better it eliminates potential threats to the company. In the beginning, the selected ERP system needs to be tailored in cooperation with experts, to the nature of the company, type of business, management of the financial agenda, 
and logistics. The local specifics of each country in which implementation takes place must also be addressed. Choosing an appropriate ERP provider, depends on many parameters [24]. First, is the condition of the company, from the point of view of current ERP systems. In some cases, calculations lead to the decision that one of the current providers that meets the requirements of a supplier to global companies will become the provider. These are complex, location-independent services, requiring a high degree of technical support when needed, the ability to change and adapt the system over time to changing companies, and its compatibility with other systems, such as the CRM system [20,29,37,38].

Many people are involved in preparations. It involves internal people who know the character of the company, but also external colleagues [39]. There are many teams created that overlap with each other. The main team determined by the board of directors creates individual teams, which are responsible for implementation in each country. Other teams are process-oriented, and their responsibility is to plan the implementation of the individual parts, including technical solutions. The teams also include external people who bring experience from other projects to project management, and their contribution lies in providing feedback on individual steps and a realistic view on the post-execution phase. Different researchers have defined different barriers and constraints which can be faced in ERP adoption and implementation. The following are the key constraints faced by companies when adopting standard ERP: Resource-intensive nature of standard ERP, long implementation time frame, and high cost of standard ERP implementation [12].

As such, implementation is planned step by step using scenario methods [12,17]. It must be performed quickly; and since the implementation of the ERP system is done while the company is in full operation, a replacement option is planned for each part of the process to ensure its operation. To eliminate and minimize errors and unexpected events, companies use the so-called trial implementation, i.e., a dry run [26], at a time when the company has a break, for example, on a weekend. Simulation of the implementation and real testing of each step takes place, giving the company real data and experience, based on which the implementation plan is further modified [29,40].

In global companies, implementation of the ERP system occurs in phases, so it is implemented gradually region by region. Each phase brings new experience and knowledge with it, leading to the acceleration and minimization of errors and unexpected events, in subsequent phases of implementation. Proceeding in order takes days to do, whilst keeping a company's day-to-day financial operations functional, i.e., the ability to accept an order, deliver the goods from the warehouse, issue an invoice, and accept payments. Even though the whole process is planned, unexpected complications may occur, so customers are informed during the preparations and are given the maximum amount of actual relevant information $[9,41]$.

After implementation, the implementation team's cooperation with a local team in the given country is necessary. Its main contribution is in communicating with customers, monitoring the negative impact of implementation, and supporting the customer. This phase determines the amount of actual losses to sales and reputation of the company because of ERP implementation, which many unexpected negative events are associated with. That is why all the local team components are included in this phase. The sales department sidelines business activities and fully focuses on supporting all customers. The financial department communicates with customers about current developments in the financial agenda, for example about late payments and invoices.

The whole implementation from the decision to the new, fully functional, and unified ERP system within a global company takes time, and its length is based on the size of the company and amount of investments in the form of money and human resources. Being a strategic investment in the development of a company, companies put a lot of emphasis on ERPs and are willing to allocate significant human and financial resources to make the implementation short, with minimal negative effects. 


\subsection{Methods and Research Process}

There are many methods to analyze the activities. To achieve the aim, this case study was carried out in the form of an expert survey, aimed at assessing the impact of a unification and implementation of the ERP system in a global company. The study included methods of systemic analysis, methods of sociological expert survey, a method of qualitative peer review, and a method for a cognitive model.

The case study is one of the frequently used ways of doing a social science research. Each method has peculiar advantages and disadvantages depending on the research questions, actual behavioral events, and focus on contemporary development. "Case studies are, by Hartley, tailor-made for exploring new processes or behaviors or ones that are little understood. Hence, the approach is pursuant to Leonard-Barton particularly useful for responding to how and why questions about a contemporary set of events" [42]. In general, the case study is a preferred strategy when "how" and "why" questions are being posed. Case studies are far from being only an exploratory strategy. Case studies can be both descriptive and explanatory. So, each strategy can be used for all three purposes-exploratory, descriptive, or explanatory [43]. Authors used exploratory and descriptive strategy.

Regardless of the continuing discussion about case studies' limitations and credibility in relative to other methods, the case study method is progressively popular among researchers and its design and content can vary [42,43]. According to Yin [43], the case study has been a common research strategy in business, social work, planning, and sociology; because the case study allows an investigation to retain holistic and relevant characteristics of real-life events. Hence, it can be said, that case studies are increasingly used as a research tool to investigate a research issue. To conclude, a case study should be easy to understand, to fulfil its purpose.

To achieve the results, we reviewed entrepreneurship and ERP systems literature to identify the current state of ERP systems implementation and unification. Secondly, we created the design of the case study. Subsequently, we collected the data connected with the preparation phase of the ERP system implementation, monitored the implementation and unification of the ERP system in a global company, and evaluated the key factors for successful implementation of the ERP system.

The study, in the form of an expert survey, focused on assessing the barriers affecting the implementation and unification of the ERP system, and sough to find out critical success factors of the ERP implementation in global companies.

The implementation methods used by ERP vendors have evolved over time to make implementation faster reducing expenses, time and effort of companies [24].

If the ERP system implementation is focused, several methods are evident on how to make and use an analysis in practice. The most common methods include classification, process, documentation, information, and evaluation. Practical experience shows that, it is appropriate to use a combination of steps to create a clearer final picture of the firm's structure and processes [26]. One of the possible steps is suggested below. An analysis of the organization structure at different degrees of precision was carried out. A summary of the basic future processes underway in the company was made and the input and output processes, the connection between them and individual sections within the company were described in order to create a complete picture of the firm's functions [12]. This kind of analysis is necessary to obtain an overview of all processes in the firm. The subsequent analysis with detailed clarification is made following the implementation aim. Prior to the actual implementation, the final step is to finalize the design of the software structure based on the analyses performed, and the subsequent design of the tools on which the system chosen will work.

The use of a fully functioning unified system for a company's resource management, may bring sizeable advantages in the organization of effective company management, quickening of reaction time to changes in the external environment, and an increase in the quality of client service, as described in Verkatraman [24] and Stumvoll and Clauss [12]. Therefore, the benefit from these losses must be thoroughly calculated and analyzed. 
The following coefficients are used to calculate the efficacy: Return on investment (ROI), total cost of ownership (TCO), and cost-benefits analysis, where their evaluation is not included in this paper. In this paper, the authors used the following methods of analysis: Monitoring, experimentation, comparison, and implementation of the ERP system.

In the paper, the authors primarily used the methods of strategic analysis, monitoring, experimentation, and comparison to implement and unify the ERP system in a specific global company.

\section{Implementation of the Enterprise Resource Planning System in the Region of Europe}

As part of the process of unification and deployment of a new ERP system in the region of Europe, the studied global company already had experience of implementation in the US and Canada. With this experience, the whole process was planned for two years from the decision. Since Europe consists of many economically, politically, and culturally diverse countries, implementation was divided into three phases. In the first phase, implementation was done in Western Europe, in the second phase Central Europe, and in the last phase, the ERP system was implemented in the remaining countries.

The first phase was crucial to the company, as Western Europe represented more than $70 \%$ of the company's total turnover. More than 700 people were involved in the preparatory phase, most of which were internal staff. This is an indicator of the importance of this step, as there are 8000 employees of the studied company globally. The internal staff team was complemented by external members.

The main implementation team, which coordinated all local teams, led the established teams. These were set up by the management of local branches, where there was always a representative from the sales, marketing, financial, logistics, service, and support departments. It was crucial to include all the relevant components of the company, so as to see all aspects and eliminate potential threats.

The planning phase for ERP system implementation in Western Europe lasted six months. With the impending implementation deadline, more communication and more detailed planning were taking place. Due to the global nature of the system deployment, it was largely realized through online media-teleconferences, videoconferences, and WebEx. Several weeks before implementation, the frequency of these planning meetings was 2-3 times a week.

The company used the possibility of a trial implementation over the weekend, when goods are not sold in a normal operation and the company's entire day-to-day operations are suspended. Implementation of a new ERP system in every Western European country has been simulated. Every partial process, and individual activity and operation in the ERP system was tested. This simulation was done two weeks before real implementation, so that it would be possible to incorporate the individual experience and knowledge into the real plan.

The implementation was subsequently performed again over the weekend. The whole new system was set up within two days, so that on Monday after the weekend implementation, it was possible to start working in the new ERP system. In addition to implementation in individual branches, the system was deployed in Europe's central warehouses and in manufacturing plants for Europe. In this way, the goal, i.e., creating a single unified ERP system for the company, was achieved.

Immediately on the first day after implementation, all tracking control KPIs were deployed. Every step in the financial and logistical agenda was monitored. Progress in production and setting of inventory limits, delivery time, quality of goods delivery, and rate of errors when delivering the goods from the warehouse were monitored. From a financial point of view, the time for invoice issuance and delivery was measured, including the frequency of errors, time for payments, and so on. The Net Promoter Score (NPS) was also introduced to track customer satisfaction. This parameter pointed to the quality of implementation and its perception by customers. This also resulted in the current decline of the company's reputation and decline in sales. For each KPI, the desired statuses and percentage of importance of the given indicators were set. 
The NPS and KPIs, were data that were updated on a weekly basis. It was available to every employee of the company, especially for local teams. The task of these local teams was to evaluate them, and use them to maximize communication with customers and eliminate customer dissatisfaction. Since customers were informed by local teams prior to implementation, it was a long-term and managed process in terms of communication. Planned ordering of goods just before implementation, one month in advance, was a positive outcome. This greatly reduced the workload of the whole implementation team, as at the time of implementation, the number of orders, deliveries, and financial transactions were minimized.

One month after implementation, all the basic operational processes were functional. Processes from the areas of logistics, finance, and sales were interconnected. It was therefore possible to start setting all the report results, sales, and operational statistics. This agenda was no longer critical in relation to customers, and its dysfunction was not a threat that would cause a loss of company reputation and current turnover. Over the next three months, all reports were set for the purposes of quarterly reporting to shareholders, as well as, reports for managing all company components-business reports, logistics reports, financial reports, and warehouse management reports in interconnectedness with production.

The set KPIs and NPS have remained the same and they have made it possible to track the progress of individual components, processes, and people in the company. The final part was to connect the ERP system with other business operations systems, especially with the CRM system. This gave the company the opportunity, not only to track the development retrospectively in the form of a report, but also the ability to efficiently plan production and stockpiles depending on real business developments in the market.

The whole process of implementing the new ERP system for Western Europe in the global company, captured in Figure 1, lasted for one year. Subsequently, it was implemented in the same sequence in Central Europe and in the remaining European countries. The same sequence of events was used as during implementation in Western Europe, but this time with experience and after elimination of errors and wrong steps, thus the second and third phases altogether lasted one year. The planned implementation, including interfacing with the CRM system, has been successfully performed within the set goal of the time of two years.

This global setup of a unified ERP system with an interconnected CRM module resulted in a significant decrease in stock inventory. In the example described, this reduction was within the range of $10-20 \%$. Thus, there is no obstruction of significant cash flows because, among other things, less production occurs. The cost of implementing the ERP system depends on many parameters such as the size of the company and the associated operational parameters-size and nature of production, stock size, number of people, and covered countries of the company, etc. The implementation of the ERP system in the European zone ranged, in terms of costs, from $15 \%$ to $20 \%$ of the annual economic result of this zone. 


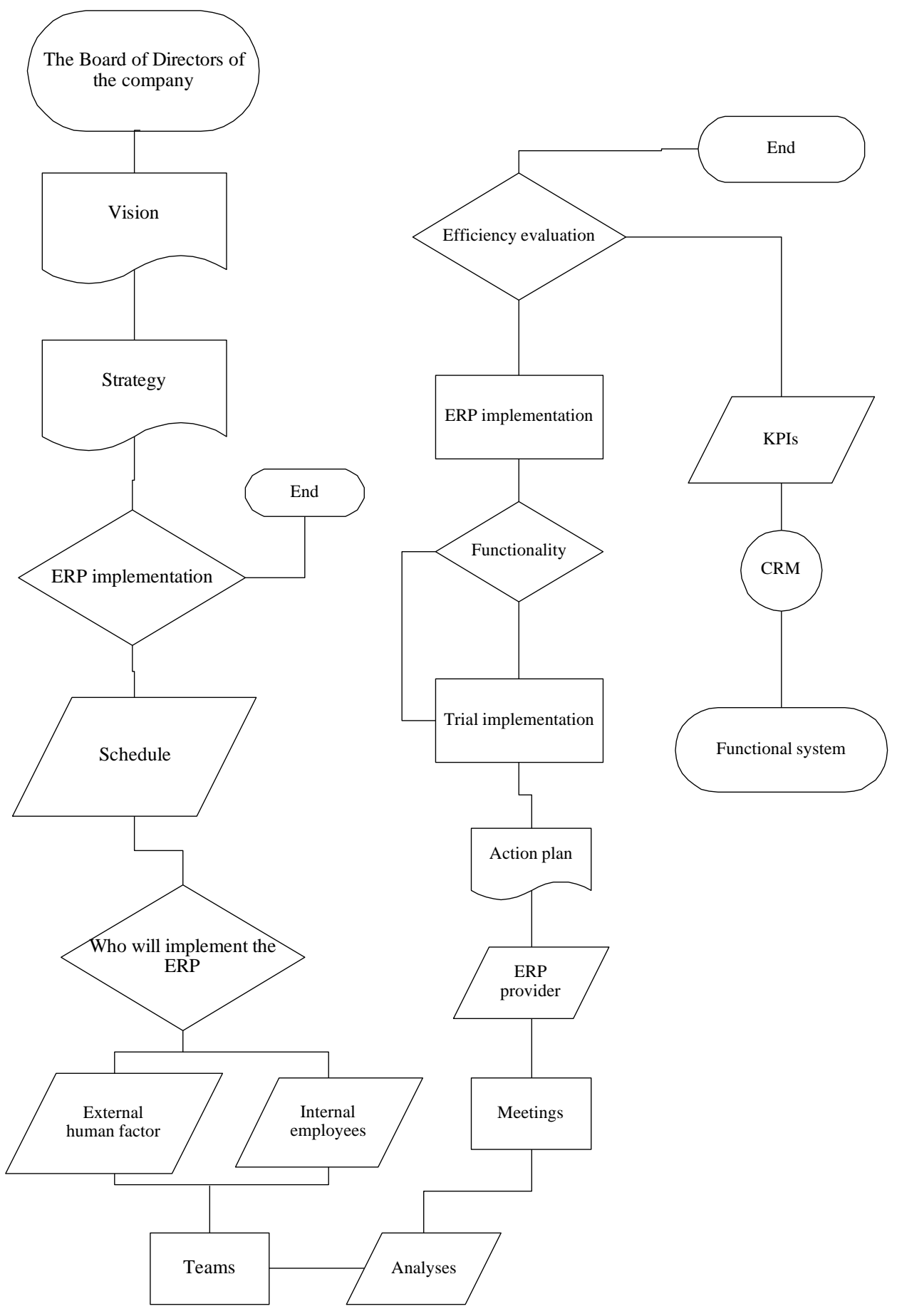

Figure 1. Enterprise Resource Planning (ERP) implementation process. NPS: Net Promoter Score; KPIs: Key Performance Indicators; CRM: Customer Relationship Management.

\section{Empirical Results and Discussion}

This study examined the relationship between implementation and unification of the ERP system and strategy of the company. The modest research effort to date has focused on the relationship between strategy implementation style and implementation success, e.g., Reference [44]. The performance effects of discrete implementation styles, e.g., Reference [45] or is undertaken in Western organizational settings, e.g., Reference [46]. 
This case study focused on the process of unification and implementation of the ERP system in a global company traded on the NASDAQ Stock Exchange. The authors monitored the preparatory phase of the ERP implementation, implementation itself, and in the second year after the implementation, they evaluated the effectiveness of the unified ERP system in the monitored organization. The preparatory phase lasted two years, involved 800 people, i.e., $17 \%$ of the company's employees in the monitored European area. The preparatory phase included two levels. In each country, that is at local level, the local team call meetings were held regularly together with a global implementation team. Within these 3-h calls once a week, all functional levels of local management (operations, finance, marketing, etc.) were represented. At the global level, there were on average 20 interviews per week.

In the original management system, the monitored company used 21 different ERP systems, which were not compatible with each other. Given the requirements of the efficiency of management, transparency, and unification of marketing activities, a unified ERP system was required. The company in its original state had approximately 2000 licenses under 21 different ERP systems. This system was financially demanding because the average annual license fee was around $5000 €$. High cost of service, training, and possible modifications were the side effects of many different ERP systems. With a unified ERP system, the company gained a quantity discount on licenses, a more profitable service contract, uniform training throughout Europe, including the establishment of internal expert positions, which consequently saved money for minor service interventions. The work of users in a single system led to a total cost reduction of approximately $20 \%$, and in terms of time efficiency, processes were reduced by $1 / 5$ compared to the original state. The total investment into the unified ERP system was approximately $€ 80$ million, or $15 \%$ of the company's turnover in the European region. After the ERP system deployment, annual savings are $€ 20$ million, so the return on the investment was foreseen for 4 years. The authors followed the whole process of the implementation and unification of the system and evaluated the situation in the second year after the introduction. Based on the assessment of the current state, half of the investment has been returned. A competitive advantage can be seen from the economic point of view, being the effectiveness of business and marketing tools when introducing new products and the possibility of selling them from the second day after their entering into the unified ERP system. Using the previous platforms, the process of introducing a new product and selling it, lasted on average 6 weeks.

As for a basic non-economic effect of the unified system, there is a possibility to evaluate the efficiency of a system operation, transparency, and the possibility of rapid acquisitions, including their integration into the company.

As a part of the unification and implementation of the unified ERP system, there is also a possibility to monitor weaknesses, including the implementation process itself, which must be provided daily, as well as all data must be ready for transfer, to avoid duplicating or losing it. If the transfer fails, everything has to go back to the old systems, which means extra costs. Minor discrepancies in the monitored global organization after the implementation, had to be fine-tuned for a month, which led to a delay in the issuing of invoices followed by tax payments, their delays, and the consequent penalties. These aspects are perceived as minor critical factors related to the introduction of the unified ERP platform. On the other hand, a fatal problem may occur, such as a system failure, data duplication etc., which in some cases may lead to the termination of the company's activities. These are the critical factors and constraints for which most organizations do not want to move to a unified system. However, given the digitization and speed of change in the market, the transition to unified platforms will be a must for companies to compete, because they will not be able to respond to trends. Practitioners say that year-to-year growth by $2 \%$ to $3 \%$ is already unlikely in today's digitized environment, without a single ERP system in global companies.

Andrews et al. [47,48] multivariate hierarchical regression analyses suggested that a logicalincremental and a mostly rational implementation style, was associated with higher levels of effectiveness, efficiency, and equity than the other implementation styles with no clear approach associated with the lowest level of performance. These findings correspond with the results of our 
experiment. Thus, our attention here is to the nature of strategy in ERP system utilization and implementation, and to the decision-making value framework. One important dimension is the extent to which the strategy model is oriented to content or to process [49]. The content role is about deciding what to do, utilizing concepts, analytical tools, and organizational techniques [47]. It includes ideas of strategy like: setting long-term direction; and positioning, fit or alignment between purposes, means and the environment. This has been relatively significant in the private sector and has given rise to further content-focused strategic ideas [50,51]. The process role [49] is one in which the issue is not so much what decisions might emanate from the strategic approach, as it is the pattern of deliberation. In the latter case, Alford and Greve [52,53] point out that the task of the manager [54] is less to find substantive solutions as such, but more to engage relevant actors to identify and deliberate about solutions and implementation opportunities. The key issues are matters such as: Who will take part in consultation or deliberations? Who will guide the proceedings? What information will be available? How much opportunity will each participant get to speak? Will proceedings be conducted in a large plenary or small groups or some other form? [55-58]. These aspects have been included by the authors in the development chart of the ERP implementation process, shown in Figure 1.

It can be said that the most important phase of the entire implementation process is the preparatory phase. The preparatory phase takes place at both local and global levels. This diversity is extremely important to cover local specifics, including legislative and legal requirements in a given country. This whole process therefore brings many threats for incomplete or even poor implementation. If this happens and a new ERP system is implemented incompletely, then a very difficult situation for the company occurs. The reason for such situation, is that to change and modify such an incompletely implemented ERP system it is very difficult, costly, and time-consuming. An avalanche effect may occur, and patches can block the entire system.

According to Nutt [59], it is said that half of the decisions in organizations result in failure. The key reason for so many failures, is that those decisions occurred predominantly during implementation rather than during decision-making. The authors also identify with this opinion in terms of the private sphere. Based on the verification of these claims, the authors conclude that, without quality and detailed preparation, very negative, even destructive effects can occur during the implementation phase. In practice, there is a full focus of companies on the preparation and implementation of the ERP system. Only when the new system is fully operational companies will go further, and this system is complemented by other modules and processes to create a unified and transparent operational, business, and marketing environment in the company.

Stewart and Kringas [46] suggested that public organizations needed to achieve a fit between strategic orientation and style of implementation, if higher levels of performance are to be attained. Michelberger and Horvath [36] saw that high importance is attached during the process resource planning to security of business processes, as well as, or instead of, optimization calculations. The integration and common application of extended ERP to Manufacturing Resource Planning (MRP II) and reinterpreted Business Continuity Management (BCM) can provide new opportunities in process management. A key contributor to corporate operations security, is the availability of resources with provisions for replacement/substitution in an acceptable period, in the event of shortage.

Based on our research within the global company, it is possible to verify the Umble et al. [15] research that ERP implementation can bring positive effects to the business. A significant and somewhat unexpected improvement was in inventory control within the case study [15]: "By utilizing system rules for lot/location control, the warehouse space requirement was reduced by $40 \%$. Inventory accuracy increased from $94.5 \%$ to $98.8 \%$. The improved accuracy would be astonishing even if the error tolerance remained unchanged, but in fact, the current tolerance is much stricter than that used in the past. Previously, a cycle count was considered "bad" if the error was greater than $0.5 \%$ of six months usage. The current standard is that the cycle count is "bad" if there is any variance, in any location, or any lot number. The accuracy level is $99.6 \%$ in locations that are wholly under control of the warehouse system." 
An effective unified environment is, for example, an ERP system linking with a company's CRM module, which can be further linked to the approval process of individual businesses. This unified part, in addition to transparency, speed and flexibility, also makes it an important element in managing the profitability of the company as a whole, and refers also to an individual country or a product group. This example, of linking a company's operations with a trade or management or company profit is an incredible advantage for managing a company on a global basis, and to prioritize individual products or countries of interest.

\section{Conclusions}

The unification and implementation of the ERP system by global companies is a very costly and long process. However, it is strategically natural and essential for long-term growth, for the possibility of acquisition activities, or for the company to be prepared for sale. Together with the benefits mentioned above, the unification and implementation of a single ERP system brings several limitations. As mentioned, there are several global providers, but cooperation with them is very similar. Perhaps the most important phase of the entire implementation process is the preparatory phase and the whole design of the system. Therefore, employees of a company of different positions and different functions are included in this phase to be able to cover all areas of operations where the ERP system will interfere. They, in cooperation with the provider and external consultants, design each process and transfer the new ERP system to each function. If a company can connect this globally unified ERP system with other business operation systems, it obtains a tool for effective corporate governance. It is then able to interconnect business activities and market forecasts with development, production, and the warehouse system. By doing so, the company is able to develop a system that significantly reduces costs thanks to more accurate and up-to-date planning. In the monitored case study of the global organization it was $20 \%$ of the total cost. Interconnectedness of the ERP system and the CRM system also allows a company to see a globally wider business and operational context, currently and up to the required time base, within one system. Consequently, it is possible to set both short-term and long-term strategies.

By setting up this system, it is also possible to monitor the KPIs [16] and NPS [41] in each country with the same parameters. It is also possible to compare them and implement positive trends from one country to another. With this setting, global companies can leverage their global reach and transfer current successful trends, processes, and activities, and compete with local players in the market. The authors found the following critical success factors of ERP implementation in global companies:

- functional top-management,

- business processes setting-affecting the long-term strategic planning, and organizational structure,

- effective communication in the organization and with the ERP vendors,

- customization of the ERP system, according to the organizations requirements and involvement of the top-management, and

- $\quad$ adequate end-users training.

The case of implementing a unified ERP system in a global company in Europe described above, demonstrates the topicality of the given subject. It also points to an enormous dependence on human and financial resources. However, despite its complexity, it is perceived as an investment in the future of the company. With a one-year gap, it is rated very positively, and despite the short-term negative effects, today's system is used daily to manage the company, business, production planning, and warehousing. There was a significant decrease in production costs and a decrease in the value of stockpiles, which in turn positively affected the financial indicators reported on the stock exchange with quarterly regularity. Now more than ever, companies need to streamline processes to enhance productivity, increase efficiency, lower costs, empower employees, and gain flexibility in today's dynamic business environment. To achieve this goal, organizations' have been integrating data within 
and also across processes, which is the core objective of an ERP system [24]. "Flexibility to adapt to a changing environment is mandatory for companies, and this requires agility, Lidl cancels SAP introduction after spending $500 \mathrm{M}$ Euro and seven years. Implementations should require months (perhaps 12-18 months in complex businesses) not many years" [60].

The research results showed that the effect of the implementation and unification of the ERP system depends, particularly, on the preparedness of the data. Implementation of an ERP system brings non-financial improvements, which are probably the most significant. After the implementation of the ERP system, organizations are positioned to sustainably grow and pursue new partnership opportunities. However, the research was only based on data from a single global company and literature review, which must be considered a limiting factor. Therefore, follow-up research will focus on verifying the effect of the ERP system on innovation performance in other industries, and in medium and large enterprises. The research samples will include a mix of various industries where the ERP system is used.

Author Contributions: All the authors conceived and designed the research, analyzed the data and wrote the paper.

Funding: This article was supported by Student Grant Competition project (SP2018/144) of Faculty of Economics, VŠB-Technical University of Ostrava.

Conflicts of Interest: The authors declare no conflict of interest. The funders had no role in the design of the study; in the collection, analyses, or interpretation of data; in the writing of the manuscript, and in the decision to publish the results.

\section{References}

1. Bird, B. Implementing entrepreneurial ideas-The case for intention. Acad. Manag. Rev. 1988, 13, 442-453. [CrossRef]

2. Žižka, M.; Valentová, V.H.; Pelloneová, N.; Štichhauerová, E. The effect of clusters on the innovation performance of enterprises: Traditional vs new industries. Entrep. Sustain. Issues 2018, 5, 780-794. [CrossRef]

3. Ernst, H.; Vitt, J. The influence of corporate acquisitions on the behaviour of key inventors. $R$ D Manag. 2000, 30, 105-119. [CrossRef]

4. Krueger, N.F.; Reilly, M.D.; Carsrud, A.L. Competing models of entrepreneurial intentions. J. Bus. Ventur. 2000, 15, 411-432. [CrossRef]

5. Orlova, L.; Gagarinskaya, G.; Gorbunova, Y.; Kalmykova, O. Start-ups in the field of social and economic development of the region: A cognitive model. Entrep. Sustain. Issues 2018, 5, 795-811. [CrossRef]

6. Farah, A.B.; Gomez-Ramos, A. Competitiveness vs. Sustainability: An Assessment of Profitability as a Component of an Approach on "Sustainable Competitiveness" in Extensive Farming Systems of Central Spain. Sustainability 2014, 6, 8029-8055. [CrossRef]

7. Salvioni, D.M.; Gennari, F.; Bosetti, L. Sustainability and Convergence: The Future of Corporate Governance Systems? Sustainability 2016, 8, 1203. [CrossRef]

8. Stverkova, H.; Pohludka, M. Business organisational structures of global companies: Use of the territorial model to ensure long-term growth. Soc. Sci. 2018, 7, 98. [CrossRef]

9. Sanchis Palacio, J.R.; Climent, V.C.; Suanes, A.M. Key factors in cooperatives creation and development: Empirical study applied to Valencian lands. Revesco-Rev. Estudios Coop. 2015, 119, 183-207. [CrossRef]

10. Boyd, B.K.; Reuning-Elliot, E. A measurement model of strategic planning. Strat. Manag. J. 2005, 34, 355-368. [CrossRef]

11. Davenport, T.H. Putting the enterprise into the enterprise system. Harward Bus. Rev. 1998, 76, 121-131.

12. Stumvoll, U.; Claus, T. Challenges while Updating Planning Parameters of an ERP System and How a Simulation-Based Support System Can Support Material Planners. Systems 2016, 4, 10. [CrossRef]

13. Bakala, A.M.; Sankowski, D. Managing the ERP teaching process. Pol. J. Manag. Stud. 2015, 12, 15-25.

14. Liand, H.G.; Saraf, N.; Hu, Q.; Xue, Y.J. Assimilation of enterprise systems: The effect of institutional pressures and the mediating role of top management. MIS Q. 2007, 31, 59-87.

15. Umble, E.J; Haft, R.R.; Umble, M.M. Enterprise resource planning: Implementation procedures and critical success factors. Eur. J. Oper. Res. 2003, 146, 241-257. [CrossRef] 
16. Hong, K.K.; Kim, Y.G. The critical success factors for ERP implementation: An organizational fit perspective. Inf. Manag. 2002, 40, 25-40. [CrossRef]

17. Plenkina, V.; Andronova, I.; Deberdieva, E.; Lenkova, O.; Osinovskaya, I. Specifics of strategic managerial decisions-making in Russian oil companies. Entrep. Sustain. Issues 2018, 5, 858-874. [CrossRef]

18. Waas, T.; Huge, J.; Block, T.; Wright, T.; Benitez-Capistros, F.; Verbruggen, A. Sustainability Assessment and Indicators: Tools in a Decision-Making Strategy for Sustainable Development. Sustainability 2014, 6, 5512-5534. [CrossRef]

19. Miller, S. Implementing Strategic Decisions: Four Key Success Factors. Organ. Stud. 1997, 18, 577-602. [CrossRef]

20. Hambrick, D.C.; Cannella, A.A. Strategy Implementation as Substance and Selling. Acad. Manag. Exec. 1989, 3, 278-285. [CrossRef]

21. Kim, H.S.; Kim, Y.G. A CRM performance measurement framework: Its development process and application. Ind. Mark. Manag. 2009, 38, 477-489. [CrossRef]

22. Mintzberg, H. The Rise and Fall of Strategic Planning: Reconceiving Roles for Planning, Plans, Planners; The Free Press: New York, NY, USA, 1994; ISBN 978-1476754765.

23. Pollanen, R.; Abdel-Maksoud, A.; Elbanna, S.; Mahama, H. Relationships between Strategic Performance Measures, Strategic Decision-making, and Organizational Performance: Empirical Evidence from Canadian Public Organizations. Public Manag. Rev. 2016, 19, 725-746. [CrossRef]

24. Venkatraman, S.; Fahd, K. Challenges and Success Factors of ERP Systems in Australian SMEs. Systems 2016, 4, 20. [CrossRef]

25. Maddison Warren, A. Increasing the Value of Research: A Comparison of the Literature on Critical Success Factors for Projects, IT Projects and Enterprise Resource Planning Projects. Systems 2016, 4, 33. [CrossRef]

26. Cyrus, K.M.; Aloini, D.; Karimzadeh, S. How to Disable Mortal Loops of Enterprise Resource Planning (ERP) Implementation: A System Dynamics Analysis. Systems 2018, 6, 3. [CrossRef]

27. Campbell, A.J. Creating customer knowledge competence: Managing customer relationship management programs strategically. Ind. Mark. Manag. 2003, 32, 375-383. [CrossRef]

28. Ptak, C.A.; Schragenheim, E. ERP: Tools, Techniques, and Applications for Integrating the Supply Chain, 2nd ed.; CRC Press: London, UK, 2016; ISBN 978-1574443585.

29. Cliff, S. ERP implementation-How to avoid $\$ 100$ million write-offs. Harward Bus. Rev. 1999, 77, $16-17$.

30. Monk, F.; Wagner, J. Concepts in Enterprise Resource Planning, 3rd ed.; Course Technology Cengage Learning: Boston, MA, USA, 2009; ISBN 978-1111820398.

31. Hrebiniak, L.G.; Joyce, W.F. Implementing Strategy; Macmillan: New York, NY, USA, 1984; ISBN 978-0023575402.

32. Ajzen, I. Organizational behavior and human decision processes. ScienceDirect 1991, 50, 179-211. [CrossRef]

33. Kuchta, D.; Klaus-Rosinska, A.; Ropuszyndska-Surma, E.; Walecka-Jankowska, K. Treats to research projects across the project life cycle. Forum Sci. Oecon. 2017, 5, 71-87.

34. Andrews, R.; Beynon, M.J.; Genc, E. Strategy Implementation Style and Public Service Effectiveness, Efficiency, and Equity. Adm. Sci. 2017, 7, 4. [CrossRef]

35. Zhao, F.; Kirche, E.T. ERP On-Premise or On-Demand. Int. J. Bus. Anal. 2018, 5, 1-16. [CrossRef]

36. Michelberger, P.; Horvath, Z.S. Security aspects of process resource planning. Pol. J. Manag. Stud. 2017, 16, 142-153. [CrossRef]

37. Kovalova, M. People in the process of innovation and as the factor increasing business performance. Forum Sci. Oecon. 2016, 4, 15-26.

38. Okreglicka, M.; Mynarzova, M. Reasonableness and restrictions of the use of lean management in small business. In Aktualne Problem Podnikovej Sfery; Toth, M., Ed.; Ekonom: Bratislava, Slovak, 2015; pp. 519-528. ISBN 978-80-225-4077-3.

39. Kmecova, I. Survey analysis of business potential and aptitude for business. Forum Sci. Oecon. 2016, 4, 151-162.

40. Kovacs, G.Y.; Kot, S. New logistics and production trends as the effect of global economy changes. Pol. J. Manag. Stud. 2016, 14, 115-126. [CrossRef]

41. Fader, P.S.; Hardie, B.G.S.; Lee, K.L. RFM and CLV: Using ISO-value curves for customer base analysis. J. Mark. Res. 2005, 42, 412-430. [CrossRef]

42. Meyer, C.B. A case in Case study Methodology. Field Methods 2001, 13, 329-352. [CrossRef] 
43. Yin, R. Case Study Research: Design and Methods (Applied Social Research Methods), 3rd ed.; SAGE Publications: Thousand Oaks, CA, USA, 2002; ISBN 978-0761925521.

44. Hickson, D.J.; Miller, S.C.; Wilson, D.C. Planned or Prioritized? Two Options in Managing the Implementation of Strategic Decisions. J. Manag. Stud. 2003, 40, 1803-1836. [CrossRef]

45. Andrews, R.; Boyne, G.A.; Law, J.; Walker, R.M. Strategy Implementation and Public Service Performance. Adm. Soc. 2011, 43, 643-671. [CrossRef]

46. Stewart, J.; Kringas, P. Change Management-Strategy and Values in Six Agencies from the Australian Public Service. Public Adm. Rev. 2003, 63, 675-688. [CrossRef]

47. Andrews, R.; Boyne, G.A.; Walker, R.M. Strategy Content and Organizational Performance: An Empirical Analysis. Public Adm. Rev. 2006, 6, 52-63. [CrossRef]

48. Andrews, R.; Boyne, G.A.; Law, J.; Walker, R.M. Centralization, Organizational Strategy, and Public Service Performance. J. Public Adm. Res. Theory 2009, 19, 57-80. [CrossRef]

49. Alford, J. The Implications of "Publicness" for Strategic Management Theory. Exploring Public Sector Strategy; Gerry, J., Kevan, S., Eds.; Prentice-Hall: London, UK, 2001; pp. 1-16. ISBN 978-0273646877.

50. Boyne, G.A.; Walker, R.M. Strategy Content and Public Service Organizations. J. Public Adm. Res. Theory 2004, 14, 231-252. [CrossRef]

51. Alford, J.; Douglas, S.; Geuijen, K.; Hart, P. Ventures in public value management: Introduction to the symposium. Public Manag. Rev. 2017, 19, 589-604. [CrossRef]

52. Greve, C. Ideas in public management reform for the 2010s. Digitalization, value creation and involvement. Public Organ. Rev. 2015, 15, 15-49. [CrossRef]

53. Alford, J.; Greve, C. Strategy in the Public and Private Sectors: Similarities, Differences and Changes. Adm. Sci. 2017, 7, 35. [CrossRef]

54. Miller, D. Successful Change leaders: What Makes Them? What Do They Do That Is Different? J. Chang. Manag. 2002, 2, 359-368. [CrossRef]

55. Mintzberg, H. Patterns in Strategy Formation. Manag. Sci. 1978, 24, 934-948. [CrossRef]

56. Stead, J.G.; Stead, W.E. Sustainable Strategic Management, 2nd ed.; Routledge: New York, NY, USA, 2014; ISBN 978-1317459149.

57. Pinto, J.K.; Prescott, J.E. Planning and Tactical Factors in the Project Implementation Process. J. Manag. Stud. 1990, 27, 305-327. [CrossRef]

58. Ostroff, C.; Schmitt, N. Configurations of Organizational Effectiveness and Efficiency. Acad. Manag. J. 1993, 36, 1345-1361. [CrossRef]

59. Nutt, P.C. Leverage, Resistance and the Success of Implementation Approaches. J. Manag. Stud. 1998, 35, 213-240. [CrossRef]

60. Cravero, A. Lidl Cancels SAP Introduction after Spending 500M Euro and Seven Years. Available online: https:/ / www.Linkedin.com/pulse/lidl-cancels-sap-introduction-after-spending-500m-euro-andreacravero/ (accessed on 30 June 2018).

(C) 2018 by the authors. Licensee MDPI, Basel, Switzerland. This article is an open access article distributed under the terms and conditions of the Creative Commons Attribution (CC BY) license (http://creativecommons.org/licenses/by/4.0/). 